\title{
Dural Metastases in Chronic Myeloid Leukemia Presenting as Subdural Hematoma
}

\author{
Kronik Myeloid Lösemide Subdural Hematom Olarak Ortaya Çıkan \\ Dural Metastazlar
}

Bodapati Chandramouliswara PRASAD, Vemula Venkata Ramesh CHANDRA, Gangumolu VARAPRASAD

SVIMS, Department of Neurosurgery, Tirupati Ap, India

Correspondence address: Vemula Venkata Ramesh CHANDRA / E-mail: rcvv@in.com

\begin{abstract}
Subdural hematoma (SDH) has been reported in $0.5-4 \%$ of all intracranial metastatic tumors. Chronic SDH has been reported in intracranial metastases from both solid and haematological malignancies. Here we report recurrent SDH in a patient with chronic myeloid leukaemia (CML) following dural metastases. An elderly male patient a known case of CML was admitted to our casualty with symptoms of headache and altered sensorium and imaging revealed a large right fronto temporo parietal chronic SDH. This was surgically managed and histopathology of the duramater and subdural membrane confirmed infiltration with leukemic cells. The pathogenesis of chronic SDH in malignancies is multifactorial and this case report throws light on leukemic infiltration of duramater as a cause for chronic SDH other than coagulopathy.
\end{abstract}

KEYWORDS: Dural metastases, Subdural hematoma, Leukemia

öz

Subdural hematom (SDH) tüm intrakraniyal metastatik tümörlerin \%0,5-4'ünde bildirilmiştir. Kronik SDH hem solid hem hematolojik malignansilerden intrakraniyal metastazlarda bildirilmiştir. Burada kronik myeloid lösemili (KML) bir hastada dural metastazlardan sonra reküran SDH bildiriyoruz. Bilinen KML olgusu olan yaşlı bir erkek hasta acil servisimize başağrısı ve bilinçte değişiklikle geldi ve görüntüleme büyük bir sağ frontotemporoparietal kronik SDH gösterdi. Bu durum cerrahi olarak tedavi edildi ve duramater ve subdural membran histopatolojisi lösemik hücrelerle infiltrasyonu doğruladı. Malignansilerde kronik SDH patogenezi multifaktoriyaldir ve bu olgu raporu kronik SDH nedeni olarak koagülopati dışında duramaterin lösemik infiltrasyonunu aydınlatmaktadır.

ANAHTAR SÖZCÜKLER: Dural metastazlar, Subdural hematom, Lösemi

\section{INTRODUCTION}

Subdural hematoma (SDH) has been reported in $0.5-4 \%$ of all intracranial metastatic tumours (6). Chronic SDH has been reported in intracranial metastases from both solid and haematological malignancies. There are very few articles dealing with the pathogenesis and management of subdural hematomas in patients with intracranial metastases (1-6). Here we report recurrent SDH in a patient with chronic myeloid leukaemia (CML) following dural metastases.

\section{CASE REPORT}

A 56-year-old male patient presented to neurosurgery emergency with history of headache and forgetfulness for two weeks and sudden onset weakness of left side of the body and loss of consciousness for one day. He was a known patient of CML and was on regular treatment for the past three years. On examination he was hemodynamically stable and on neurological examination he was comatosed with Glascow coma scale (GCS) of nine. He also had pupillary asymmetry and left hemiparesis. Computed tomography (CT) of brain revealed a large right fronto-temporo-parietal chronic SDH with midline shift. Coagulation parameters were normal. In view of his poor GCS a right parietal twist drill was put and evacuation of chronic SDH was done. Repeat CT scan showed significant evacuation of chronic SDH. The patient recovered well and was discharged. The patient was readmitted to casualty two weeks after discharge with history of headache and loss of consciousness. On examination, the patient was comatose with a GCS of five. The patient was intubated and CT brain was done that revealed fronto-temporo-parietal chronic SDH. The coagulation profile was within normal limits. Immediate evacuation of SDH was done with a brain cannula kept through the previous twist drill site. The GCS of the patient improved to twelve. He underwent right frontal and parietal burr holes and evacuation of chronic SDH. Subdural membrane along with a part of duramater was sent for biopsy and chronic SDH fluid was sent for malignant cells. The fluid was negative for malignant cells but the biopsy revealed leukemic infiltration of subdural membrane (Figure 1A, B). He recovered well and was fully conscious without any deficit at the time of discharge. He was discharged and referred to oncologist for further management. 

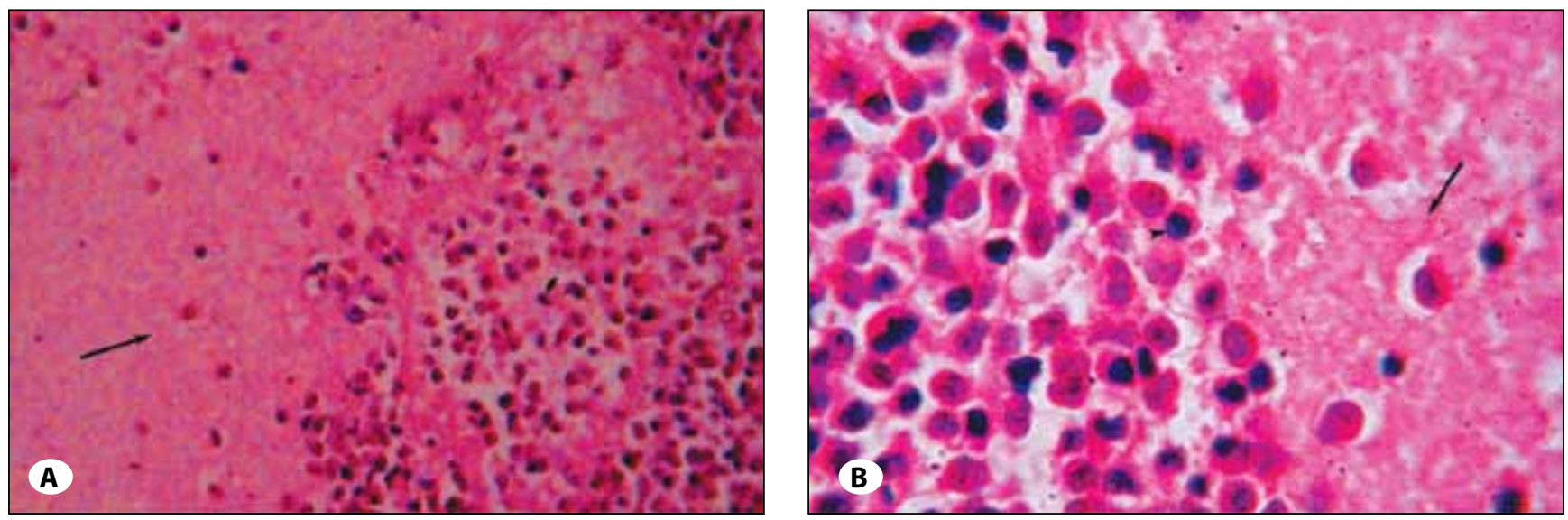

Figure 1: A) Dural (arrow) infiltration with leukemic cells (arrow head) (HE Lower magnification). B) Dural (arrow) infiltration by leukemic cells (arrow head) (HE high magnification).

\section{DISCUSSION}

Subdural hematomas in patients with malignancy can be grouped into those occurring due to some predisposing factors and those occurring spontaneously. Predisposing factors could be previous head trauma, alcoholism or anticoagulation. Subdural hematomas occurring due to some predisposing factors were more commonly seen in solid tumours whereas spontaneous subdural hematomas were associated with haematological malignancies (5). The case reported here did not have any predisposing factor for subdural hematoma and was associated with CML in line with the reviewed literature. Among haematological malignancies SDH was more frequently associated with acute leukemias rather than chronic leukemias or lymphomas $(1,3)$. Here spontaneous SDH is reported in a case of chronic haematological malignancy that makes it unique. The exact pathogenesis of spontaneous SDH in haematological malignancies have been attributed to many factors including dural blood vessel occlusion by tumoral cells that may rupture within the subdural compartment (4), tumor necrosis, chemotherapy-induced thrombocytopenia or disseminated intravascular coagulation secondary to underlying malignancy (2). This case suggests that dural metastases from haematological malignancies should be considered as a pos- sibility other than thrombocytopenia especially in patients of haematological malignancies with recurrent SDH.

\section{REFERENCES}

1. Bromberg JE, Vandertop WP, Jansen GH: Recurrent subdural haematoma as the primary and sole manifestation of chronic lymphocytic leukaemia. Br J Neurosurg 12:373-376,1998

2. ChenCY, Zimmerman RA,Faro S, Bilaniuk LT,ChouTY, Molloy PT: Childhood leukemia: Central nervous system abnormalities during and after treatment. Am J Neuroradiol 17:295-310, 1996.

3. Jourdan E, Dombret $H$, Glaisner S, Miclea JM, Castaigne $S$, Degos L: Unexpected high incidence of intracranial subdural haematoma during intensive chemotherapy for acute myeloid leukaemia with a monoblastic component. $\mathrm{Br} J$ Haematol 89:527-30, 1995

4. Laigle DF, Taillibert S, Mokhtari K, Hildebrand J, Delattre JY: Dural metastases. J Neurooncol 75:57-61, 2005

5. Minette SE, Kimmel DW: Subdural hematoma in patients with systemic cancer. Mayo Clin Proc 64:637-642, 1989

6. Posner JB, Chernik NL: Intracranial metastases from systemic cancer. Adv Neurol 19:579-592, 1978 